\title{
Clinical experience with automatic midline echoencephalography: cooperative study of three neurosurgical clinics ${ }^{1}$
}

\author{
M. KLINGER, E. KAZNER, ${ }^{2}$ TH. GRUMME, V. AMTENBRINK, G. GRAEF, \\ K. H. HARTMANN, H. HOPMAN, W. MEESE, AND B. VOGEL
}

From the Neurosurgical University Clinics, Berlin, Erlangen, and München, GFR

SYNOPSIS Computerized midline echoencephalography was developed in order to make the determination of the midline more objective. In a group study involving the neurosurgical clinics in Berlin, Erlangen, and Munich, a total of 1889 patients with various intracranial diseases was examined by this method. An exact analysis of the results obtained is presented: $18 \%$ were unsatisfactory.

A-scan echoencephalography has become widely used in recent years and is now an indispensable tool in the diagnosis of intracranial lesions (Grossman, 1966; Pia and Geletneky, 1968; Schiefer et al., 1968). However, the literature contains many reports on the difficulties this method presents, especially for the beginner (McKinney, 1964; Jefferson and Hill, 1966, 1968; Kramer, 1968; White, 1967, 1970, 1972; White and Hanna, 1974). Experienced investigators have emphasized for years that prolonged practice is necessary before echoencephalography can yield truly reliable and accurate results. Comparing the error rates of various authors, it becomes evident that the percentage of mistakes is considerably higher in smaller series than when the number of examinations exceeds 300 patients (Schiefer et al., 1968). An error quota of over $10 \%$ in some series rapidly led to disappointment and to a discreditation of A-scan echoencephalography. Since some authors of large series were able to achieve an accuracy as high as $99 \%$, special emphasis was placed on the condition that echoencephalography should be performed only by physicians with adequate training. Naturally

1 Presented at the 2nd DAUD-meeting in Hanover, 18 May 1974.

2 Address for correspondence: Priv. Doz. Dr E. Kazner, Neurochirurgische Klinik im Klinikum Grosshadern der Ludwig-Maximilians-Universität, D-8000 München 70, G.F.R.

(Accepted 24 September 1974.) this would limit the number of investigators considerably. White (1972), on the other hand, goes so far as to say that he does not consider such a test to be of clinical value if it depends upon the presence of a neurological specialist.

\section{METHOD}

In an effort to eliminate as much as possible the factor 'experience' in the determination of the midline echo and to provide scientific objectivity, there has been no lack of attempts to standardize this examination, especially on the North American continent. White and his research group were particularly active in searching for an automation of this diagnostic procedure which would exclude the subjective influence of the examiner so that paramedical personnel could quickly learn to handle the equipment.

In the search for suitable apparatus, Galicich and Williams (1971) attempted to achieve the following goals:

1. Substitution of criteria for automatic pattern recognition for the decision of the operator.

2. Concentration of the attention of the operator to applying the detector probe to the patient's head.

3. Acquisition and recording of enough singleorientation values to establish statistical confidence in the echo pattern detected.

In 1971 Galicich and Williams presented the automatic midline computer, known as the Midliner, that seemed to fulfill these conditions (Fig. 1). The 




FIG. 1 Investigation with the Midliner. Note lack of oscilloscope. Readings appear on digital scale. principle of operation is explained in Fig. 2. A $2 \mathrm{MHz}$ transducer with a pulse repetition rate of 500 cycles is applied in the hair-free zone above the ear. The computer first searches for the double end echo, one echo coming from the inner table of the skull and the other from the skin-air interface. Upon finding the distal echo, the computer measures the diameter of the skull and automatically determines the theoretical midline by dividing the distance from probe to distal echo in half. Now the mid-gate is opened to search for the midline echo. The gate area is limited to $32 \mathrm{~mm}$-that is, $16 \mathrm{~mm}$ to the right and to the left of the theoretical midline, thus comprising about $20 \%$ of the total distance. If the computer finds a single high echo here, the position of this echo is shown as a lit-up number on the digital scale. Simultaneously a $500 \mathrm{~Hz}$ tone is heard. If the computer fails to find a single high echo in the gate area or registers several high echoes, the digital scale remains dark and the computer begins anew with the determination of the digital echo.

When a successful measurement has been made the number appears on the digital scale and this number is recorded on a special data sheet with different symbols for the right and the left side. Subsequently a new cycle is initiated by pressing on the reset button. The examination from one side is completed if one column is filled. Galicich and Williams (1971) called the completed data sheet a histogram to distinguish it from the echoencephalogram or echogram. The duration of the Midliner examination depends on the number of measure-

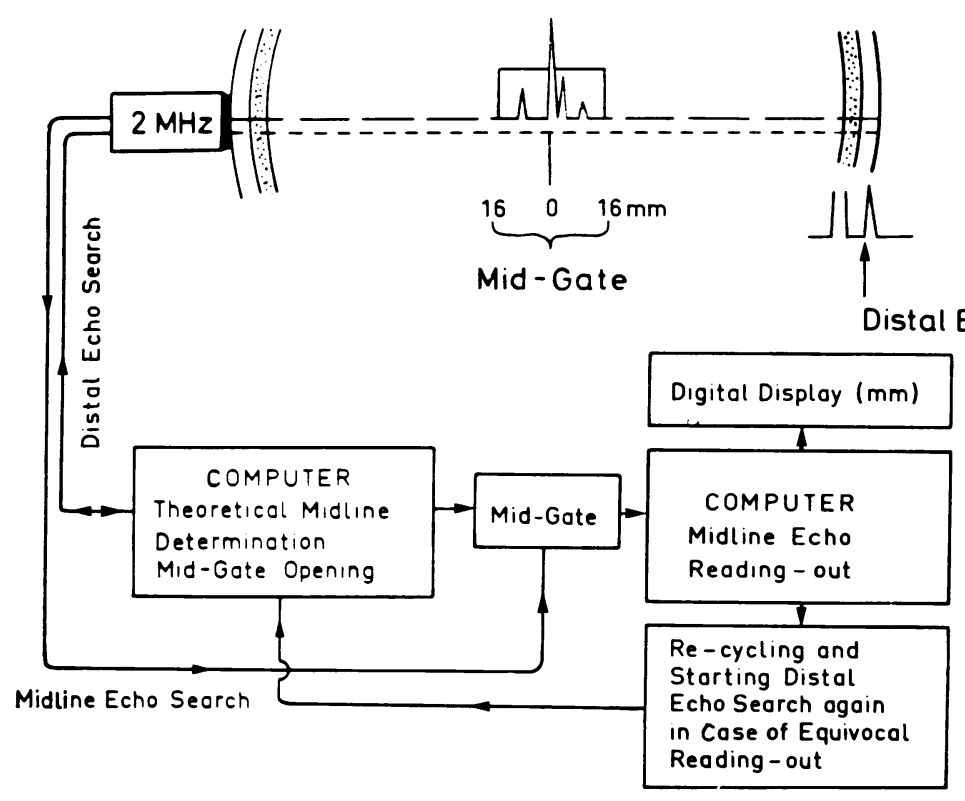

FIG. 2 Principle of computerized midline echo encephalography (after Galicich and Williams, 1971). 


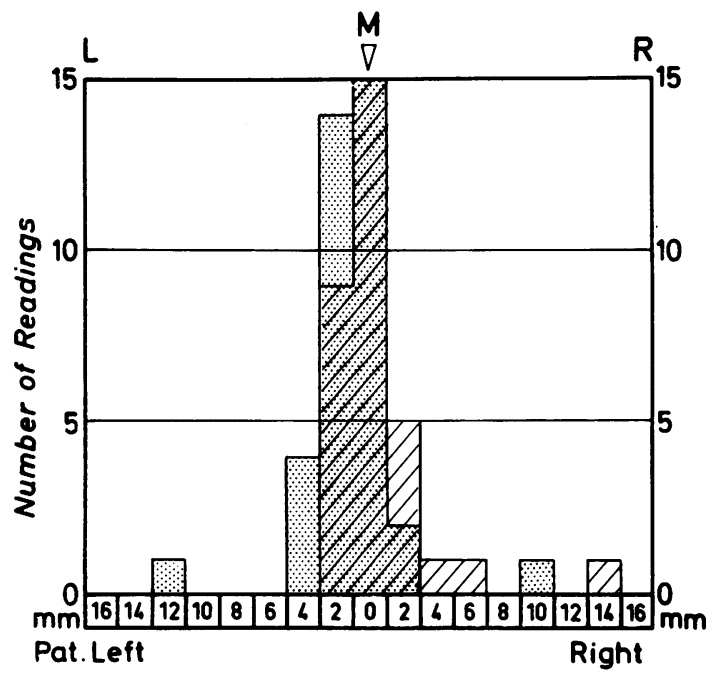

C 535

FIG. 3 Normal histogram showing a block of readings in the midline.

ments necessary before either a satisfactory or an unsatisfactory histogram has been obtained. This may take from five to as much as $\mathbf{4 0}$ minutes in difficult cases. The time can be reduced considerably to about three minutes if two persons carry out the examination together: one person handles the probe while the other concentrates on the Midliner and writes down the digits as they appear on the scale. Since a large number of measurements is made, the midline echo possesses statistical significance. Figure 3 shows a normal histogram of a patient without a shift of the midline structures. In contrast, the histogram in Fig. 4 demonstrates a distinct shift of the midline structures from left to right in a patient with a left temporal tumour. This finding stood in perfect correlation with the displacement in the A-scan echoencephalogram and with the position of the internal cerebral vein in the carotid angiogram.

In order to investigate whether the Midliner really fulfils the requirements mentioned above, a cooperative study of the neurosurgical departments of three different hospitals was carried out. Special attention was directed to the use of the Midliner in cases of head injuries suspected of having intracranial haematomas. A completely accurate determination of the midline that could be carried out by every physician in a small hospital or by paramedical personnel would have the enormous advantage of preventing the unnecessary transport of the patient over long distances. Even without the various possibilities of echoencephalography, such as the

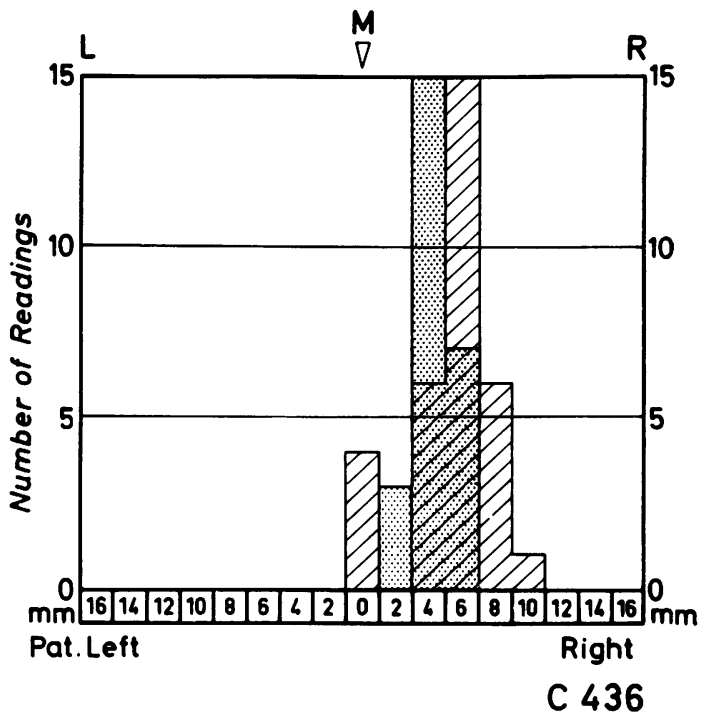

FIG. 4 Pathological histogram showing a distinct midline displacement from left to right in the presence of a tumour in the left temporal lobe.

measurement of ventricular width, the observation of tumour echo complexes or the detection of a haematoma echo, the absolutely certain determination of the midline echo would justify the use of such an automated method.

\section{RESULTS}

Altogether 1889 patients underwent the midliner investigation. Table 1 presents a survey of the diagnoses of these patients: there were 591 brain tumours, 312 head injuries, nearly 200 cases of cerebrovascular disease, and 414 patients with various intracranial diseases. Only 374 subjects were unremarkable at clinical and echoencephalographic examination and

TABLE 1

DIAGNOSES OF 1889 PATIENTS INVESTIGATED WITH AUTOMATIC MIDLINE COMPUTER

\begin{tabular}{lrrrr}
\hline & \multicolumn{2}{c}{ Number of patients investigated in } & \\
\cline { 2 - 4 } \multicolumn{1}{c}{ Diagnosis } & Berlin & Erlangen & München & Total \\
\hline Brain tumour & 127 & 183 & 281 & 591 \\
Head injury & 115 & 73 & 124 & 312 \\
Cerebrovascular lesion & 43 & 37 & 118 & 198 \\
$\begin{array}{l}\text { Intracranial disease of } \\
\quad \text { other aetiology }\end{array}$ & 95 & 20 & 299 & 414 \\
Normal & 249 & 117 & 8 & 374 \\
\hline Total & 629 & 430 & 830 & 1889 \\
\hline
\end{tabular}


TABLE 2

RESULTS OF AUTOMATIC MIDLINE DETERMINATION IN 1889 PATIENTS IN COMPARISON WITH A-SCAN ECHOENCEPHALOGRAPHY

\begin{tabular}{lccccccc}
\hline & \multicolumn{4}{c}{ Number of cases } & & \multicolumn{2}{c}{ Comparison with A-scan } \\
\cline { 2 - 7 } \multicolumn{1}{c}{ Histogram } & Berlin & Erlangen & München & Total & & Correct & Incorrect \\
\hline Normal & 322 & 277 & 512 & 1111 & $1100=99 \%$ & $11=1 \%$ \\
Midline shift & 118 & 102 & 214 & 434 & $401=92 \%$ & $33=8 \%$ \\
Unsatisfactory & 189 & 51 & 104 & 344 & \\
& $(30 \%)$ & $(12 \%)$ & $(13 \%)$ & $(18 \%)$ & & \\
\hline Total & 629 & 430 & 830 & 1889 & $1501=80 \%$ & $44=2.3 \%$ \\
\hline
\end{tabular}

TABLE 3

SURVEY OF UNSATISFACTORY AND INCORRECT HISTOGRAMS IN 388 CASES

\begin{tabular}{|c|c|c|c|c|}
\hline \multirow[b]{2}{*}{ Histogram } & \multicolumn{3}{|c|}{ Number of cases } & \multirow[b]{2}{*}{ Total } \\
\hline & Berlin & Erlangen & München & \\
\hline \multicolumn{5}{|l|}{ False positive } \\
\hline $\begin{array}{l}\text { ('shifted' in Midliner } \\
\text { although midline normal) }\end{array}$ & 15 & 8 & 10 & 33 \\
\hline $\begin{array}{l}\text { False negative } \\
\text { (normal in Midliner } \\
\text { although midline shifted) }\end{array}$ & 4 & 3 & 4 & 11 \\
\hline $\begin{array}{l}\text { Technically inadequate } \\
\text { (widely scattered measure- } \\
\text { ments, no unequivocal } \\
\text { midline) }\end{array}$ & 145 & 14 & 48 & 207 \\
\hline $\begin{array}{l}\text { No response obtainable } \\
\text { (thickness of skull, age) }\end{array}$ & \multirow{2}{*}{44} & 18 & 37 & \multirow{2}{*}{137} \\
\hline $\begin{array}{l}\text { Response from one side } \\
\text { only (trauma or swelling } \\
\text { opposite side) }\end{array}$ & & 19 & 19 & \\
\hline Total & 208 & 62 & 118 & 388 \\
\hline
\end{tabular}

these serve as the control group. Since the accuracy of the diagnosis is particularly important in these patients, all findings were compared with an A-scan echoencephalogram carried out by an experienced physician. Whereever possible, the neuroradiological findings were also compared with the histogram (see Table 7).

In order to prevent operator bias, many of the Midliner measurements were carried out by untrained students. Table 2 shows a comparison between these Midliner histograms and the A-scan echograms performed by a trained operator. In 1889 cases, the histograms were found to be normal 1111 times. In 1100 cases this was confirmed, so that the accuracy for the normal midline echo was $99 \%$. Of the 434 cases of Midliner displacement, $401(92 \%)$ were con-
TABLE 4

RESULTS OF AUTOMATIC MIDLINE MEASUREMENT IN 249 NORMAL CONTROLS OF VARIOUS AGE GROUPS (NEUROSURGICAL UNIVERSITY CLINIC, BERLIN)

\begin{tabular}{lccccc}
\hline & & \multicolumn{5}{c}{ Histogram } \\
\cline { 3 - 7 } $\begin{array}{c}\text { Age group } \\
(a)\end{array}$ & $\begin{array}{c}\text { Number } \\
\text { of cases }\end{array}$ & $\begin{array}{c}\text { Normal } \\
(\text { Correct })\end{array}$ & $\begin{array}{c}\text { Shift } \\
\text { (Incorrect) }\end{array}$ & $\begin{array}{c}\text { Unsatis- } \\
\text { factory } \\
(\text { no. })\end{array}$ \\
\hline$\%)$
\end{tabular}

firmed and thus correct and $33(8 \%)$ were incorrect. Taking the group of unsatisfactory results into consideration, which comprises no less than $18 \%$, the overall accuracy of the midline computer measurements was only $80 \%$. The high percentage of unsatisfactory histograms in the Berlin series is due to their particular age distribution, which is explained in detail below. The fact that rigid standards were applied to the interpretation of the histograms is a further reason for the large number of noninterpretable measurements. Special attention was given to two criteria: (1) the measurement must be recordable from both sides of the skull; (2) these values must form a single block which can be clearly identified as the midline echo.

Table 3 gives a survey of the 388 unsatisfactory and incorrect measurements. In 44 patients, the results of the two methods of examination (Midliner and A-scan) did not agree. The Midliner showed a displacement which could not be veri- 
TABLE 5

COMPARISON OF AUTOMATIC MIDLINE DETERMINATION AND A-SCAN ECHOENCEPHALOGRAPHY IN 196 PATIENTS WITH VARIOUS INTRACRANIAL LESIONS (NEUROSURGICAL UNIVERSITY CLINIC, ERLANGEN)

\begin{tabular}{|c|c|c|c|c|c|c|c|}
\hline \multirow[t]{2}{*}{ Diagnosis } & \multirow{2}{*}{$\begin{array}{l}\text { Number } \\
\text { of cases }\end{array}$} & \multicolumn{3}{|c|}{ Midliner } & \multicolumn{2}{|c|}{ A-scan } & \multirow{2}{*}{$\begin{array}{l}\text { Agreement } \\
(\text { no. })(\%)\end{array}$} \\
\hline & & Normal & Shift & Unsatisfactory & Normal & Shift & \\
\hline $\begin{array}{l}\text { Brain tumour } \\
\text { Head injury } \\
\text { Cerebrovascular lesion }\end{array}$ & $\begin{array}{r}132 \\
41 \\
23\end{array}$ & $\begin{array}{l}49 \\
13 \\
13\end{array}$ & $\begin{array}{r}57 \\
15 \\
7\end{array}$ & $\begin{array}{r}26 \\
13 \\
3\end{array}$ & $\begin{array}{l}62 \\
17 \\
15\end{array}$ & $\begin{array}{r}70 \\
24 \\
8\end{array}$ & $\begin{array}{ll}98 & 74.2 \\
28 & 68.3 \\
20 & 87\end{array}$ \\
\hline Total & 196 & 75 & 79 & 42 & 94 & 102 & 14674.5 \\
\hline
\end{tabular}

TABLE 6

SURVEY OF UNSATISFACTORY AND INCORRECT HISTOGRAMS IN TWO SUBSEQUENT SERIES (NEUROSURGICAL UNIVERSITY CLINIC, ERLANGEN)

\begin{tabular}{lcc}
\hline Histogram & $\begin{array}{c}\text { First series } \\
150 \text { cases }\end{array}$ & $\begin{array}{c}\text { Second series } \\
150 \text { cases }\end{array}$ \\
\hline $\begin{array}{l}\text { False positive } \\
\text { ('Shifted' in Midliner } \\
\text { although midline normal) }\end{array}$ & 6 & 1 \\
$\begin{array}{l}\text { False negative } \\
\text { (Normal in Midliner } \\
\text { although midline shifted) } \\
\begin{array}{c}\text { Technically inadequate } \\
\text { (Widely scattered measurements, }\end{array}\end{array}$ & 10 & 1 \\
$\begin{array}{l}\text { no unequivocal midline) } \\
\text { No response obtainable } \\
\text { (Thickness of skull, age) }\end{array}$ & 11 & 2 \\
\hline $\begin{array}{l}\text { Response from one side only } \\
\text { Total no. }\end{array}$ & 13 & 5 \\
Per cent & 43 & 12 \\
\hline
\end{tabular}

fied in 33 cases-that is, a false positive result. Considerably more dangerous is a false negative finding in which the midline appears to be normal in the histogram while the cerebral midline is actually displaced. However, the per- centage of such errors in the total of 1889 patients was only $0.6 \%$. Technical difficulties were met in 207 cases: most of these had histograms containing many scattered values without an unequivocal midline echo block. Since increased scatter is more likely to occur in patients with intracranial disease than in healthy subjects, the failure to obtain a single midline column must be regarded as an indication foro further diagnostic investigations, an observatio $\bar{P}$ made by White (1972) as well. Whenever th\& consistency of the skull changes-for example increased thickness of the bony skull or pneumas tization of the bone-the Midliner was unable to record a value because the ultrasoun beam is absorbed too strongly. As Table shows, this is particularly true for patients over of the age of 60 . The dependence on the age of the patient is impressively demonstrated in this series in which the high percentage of non-recordable measurements in infants is surprising. This is due to the setting of the Midliner scale which is limited to a head diameter of 13 to $18 \mathrm{~cm}$. This $\overrightarrow{\overrightarrow{0}}$ age distribution is responsible for the high per-

TABLE 7

COMPARISON OF MIDLINER RESULTS AND NEURORADIOLOGICAL FINDINGS IN 585 PATIENTS (COMPARED WITH SERIES OF 573 CASES FROM WHITE AND HANNA, 1974)

\begin{tabular}{|c|c|c|c|c|c|c|}
\hline \multirow[t]{2}{*}{ Histogram } & \multicolumn{3}{|c|}{ Klinger et al. (1975) } & \multicolumn{3}{|c|}{ White and Hanna (1974) } \\
\hline & $\begin{array}{l}\text { No. of } \\
\text { cases }\end{array}$ & $\begin{array}{c}\text { Agreement } \\
\text { with } \\
\text { neuroradiol. }\end{array}$ & $\begin{array}{c}\text { No agreement } \\
\text { with } \\
\text { neuroradiol. }\end{array}$ & $\begin{array}{l}\text { No. of } \\
\text { cases }\end{array}$ & $\begin{array}{c}\text { Agreement } \\
\text { with } \\
\text { neuroradiol. }\end{array}$ & $\begin{array}{c}\text { No agreement } \\
\text { with } \\
\text { neuroradiol. }\end{array}$ \\
\hline $\begin{array}{l}\text { Normal midline } \\
\text { Midline shift }\end{array}$ & $\begin{array}{l}233 \\
352\end{array}$ & $\begin{array}{l}225 \\
341\end{array}$ & $81(3.2 \%)$ & $\begin{array}{r}474 \\
99\end{array}$ & $\begin{array}{r}468 \\
83\end{array}$ & $\stackrel{6}{16}(16 \%)$ \\
\hline $\begin{array}{l}\text { Total } \\
\text { Per cent }\end{array}$ & $\begin{array}{l}585 \\
100\end{array}$ & $\begin{array}{l}566 \\
96.7\end{array}$ & $\begin{array}{l}19 \\
3.3\end{array}$ & $\begin{array}{l}573 \\
100\end{array}$ & $\begin{array}{l}551 \\
96.2\end{array}$ & $\begin{array}{l}22 \\
3.8\end{array}$ \\
\hline
\end{tabular}


centage of unsatisfactory histograms in the Berlin series (Table 2). A large proportion of the unsatisfactory measurements was due to the fact that the echo could be recorded only from one side or not at all (Table 4). Since a subgaleal haematoma generally prevents the detection of an unequivocal M-echo, a considerable number of patients with head injuries could not be examined. For this reason, the agreement between histogram and A-scan echoencephalogram was rather poor in this group: only $68 \%$ of the measurements in cases of head injuries were in agreement (Table 5). Because of the large number of unsatisfactory Midliner measurements, only 79 of 102 midline shifts could be detected using the Midliner $\left(77^{\circ} \%\right.$ ).

Although one would assume that the Midliner read-out is entirely objective and independent of the experience of the examiner, Table 6 contradicts this assumption. This Table shows two succeeding series of 150 cases, each performed by the same untrained student. It is obvious that the Midliner examination must be learned just like other methods. The total error rate sank from $29 \%$ in the first series of 150 cases to $8 \%$ in the subsequent group-the difference is doubtless due to experience with the Midliner technique.

\section{DISCUSSION}

Comparing these results with those in the literature shows apparently better overall results by other authors. Thus, in a series of 3333 cases, White and Hanna (1974) observed only $3 \%$ unsatisfactory results. An exact analysis of their results reveals that these were mainly normal findings $(89.7 \%)$. The accuracy in 2089 cases of normal histograms was $98.9 \%$. The comparable degree of accuracy in the series presented here is also $99 \%$. Turning to the histographic shifts, the error rate of $16 \%$ reported by White and Hanna is significantly higher than the corresponding $8 \%$ rate in our study. To make the figures truly comparable, the Midliner measurements were compared with the neuroradiological findings in both series. The results (Table 7) indicate that the difference in the percentage of incorrect values is even more significant: $16 \%$ of the measurements in the Kingston series failed to concur with the neuroradiological finding, while only $3.2 \%$ of the measurements in our group study could not be confirmed by radiological methods. Despite the good agreement shown in Table 7, the high number of unsatisfactory results is a severe drawback.

In view of the fact that the rate of unsatisfactory results ranges from 13 to $32 \%$ depending on the type of intracranial pathology (Table 5), the automatic midline computer cannot replace conventional A-scan echoencephalography, even if only the determination of the cerebral midline is considered. Therefore the Midliner can only be regarded as a first step on the way to automatic midline determination.

In some unclear cases, the use of the Midliner in addition to the A-scan echoencephalograph can provide further information so that its use as a second apparatus in a neurological or neurosurgical clinic is feasible. However, the large number of unsatisfactory measurements makes it of limited use for practising neurologists and emergency departments of small hospitals. As experience in all three hospitals involved in this study has shown, the computerized determination of the midline echo is not reliable enough to warrant its use in cases of head injury.

New techniques for the determination of the cerebral midline using ultrasound are currently being developed. The results of Hudson and Müller (1974) with a compact echoencephalograph appear promising and remain to be tested by other investigators.

\section{SUMMARY}

The examination of the brain with ultrasound has become a routine method of neurological diagnosis. Although A-scan echoencephalography has provided very good results, the need for a more objective method of determining the cerebral midline prompted the development of the automatic midline computer. The Midliner which makes fewer demands on the experience of the investigator than conventional A-scan echoencephalography, was studied in a combined study in the neurosurgical clinics in Berlin, Erlangen, and Munich. A total of 1889 patients with various kinds of intracranial pathology underwent investigation. As the results showed, the accuracy of the Midliner is 
good in cases of unshifted midline-1 100 measurements of the 1111 cases could be confirmed, which is an accuracy of $99 \%$. However, the Midliner hardly lives up to expectations, since no less than $18 \%$ - that is almost one-fifth of the values-were unsatisfactory.

\section{REFERENCES}

Galicich, J. H., and Williams, J. B. (1971). A computerized echoencephalograph. Journal of Neurosurgery, 35, 453-460. Grossman, C. C. (1966). The Use of Diagnostic Ultrasound in Brain Disorders. Thomas: Springfield, Ill.

Hudson, A. C., and Müller, H. R. (1974). A pocket-size echoencephalograph: description and first clinical results. Surgical Neurology, 2, 201-206.

Jefferson, A., and Hill, A. I. (1966). Echo-encephalography. Progress in Neurological Surgery, 1, 64-93.

Jefferson, A., and Hill, A. I. (1968). The importance of the non-midline echoes in A-scan echo-encephalography with a commentary on their relevance to the reliability of the method. In Proceedings in Echo-encephalography, pp. 6670. Edited by E. Kazner, W. Schiefer, and K. J. Zülch. Springer: New York.

Kramer, G. (1968). Difficulties in the interpretation of echoencephalographic findings with head injuries. In Proceedings in Echo-encephalography, pp. 107-110. Edited by 0 E. Kazner, W. Schiefer, and K. J. Zülch. Springer: New 7 York.

McKinney, W. M. (1964). The value of B-mode determination of midline in echoencephalography. (Abstract.) Neurology (Minneap.) 14, 259.

Pia, H. W., and Geletneky, C.-L. (1968). Echoenzephalographie. Thieme: Stuttgart.

Schiefer, W., Kazner, E., and Kunze, S. (1968). Clinical $\stackrel{\vec{\rho}}{D}$ Echo-Encephalography. Springer: Berlin.

White, D. N. (1967). The limitations of echo-encephalography. Ultrasonics, 5, 88-90.

White, D. N. (1970). Ultrasonic Encephalography. Schwabe: Basel.

White, D. N. (1972). Midline echoencephalography with the automatic midline computer - a clinical evaluation. क Computer and Biological Medicine, 2, 273-284.

White, D. N., and Hanna, L. F. (1974). Automatic midline echoencephalography. Neurology (Minneap.) 24, 80-93. 